\title{
THE HISTORICAL ASPECTS OF SARCOIDOSIS
}

\author{
By Professor Niels Danbolt, M.D. \\ Chief of the Department of Dermatology, University Hospital, (Rikshospitalet), Oslo, Norvay'
}

In modern medical literature the term 'sarcoidosis' has been used to an ever-increasing extent. It is also most important to record that the definition of this systemic disease, elaborated at a sarcoidosis conference in Washington in 1948 (Ricker, Walter and Clark, 1949), has been accepted in constantly growing circles.

This definition begins by maintaining that the aetiology of sarcoidosis is not known. This verdict is the final word of a discussion carried on rather fruitlessly for years about the possibility of sarcoidosis being of tuberculous origin. Studies of 'the chronic specific inflammation' have also shown that the histological picture of 'sarcoid tissue ' can be provoked by many different poisons. The diagnosis of this systemic disease depends primarily on a certain pattern of clinical symptoms, including the findings of radiological and histological examinations, tuberculin tests and Kveim's cutaneous test. The more numerous the component parts of this pattern, the more certain the diagnosis.

The 70 to 80 years concerned with the history of sarcoidosis have been marked by a fantastic development of medical research. The first descriptions of certain symptoms, which we must now assume most probably to be due to sarcoidosis, naturally bore the stamp of the knowledge of medicine at that time. Yet these observers were able to maintain that the morbid pictures they painted differed in certain respects from those of other diseases known at that time. Here many original observations, worthy to be kept in mind, were made. But, as we now know well, sarcoidosis may give rise to widely different clinical pictures. This is why many of the earlier descriptions seemed to belong to different diseases. Hence the variety of terms given to one and the same disease. Investigators whose contributions to sarcoidosis research were well earned came to have their names linked to this disease and this entailed still further confusion over its nomenclature.

The first important observations on the independent character of this disease were made at the end of the last century by Jonathan Hutchinson in England, by Ernest Besnier in France, and by
Caesar Boeck in Norway. But many years had to pass before it became evident that the clinical pictures painted by the above-mentioned pioneers in sarcoidosis research were expressions of one and the same disease. Yet these three investigators met at international congresses at which such cases were demonstrated.

Thus at the London congress in 1896 Hutchinson demonstrated one of his patients, but Besnier, who was present, said nothing to the effect that this case might have something in common with the clinical picture he had himself painted in 1889 with lupus pernio as title. Boeck was also present and in his later publication of 1899 he made a small reservation to the effect that his case might possibly be of the same character as that of Hutchinson's ' Mortimer's malady.' In his publication of 1899 Boeck says of Hutchinson's case: ' Several of the most experienced members of the congress had never seen the disease, and no one knew anything to say about its character.'

As early as 1869 Jonathan Hutchinson observed a case which most likely must have been one of sarcoidosis. It was published in 1875 in 'Illustration of Clinical Surgery.' But Hutchinson's most important study of this disease belongs to 1898 , when he published in his "Archives of Surgery" (Hutchinson) a study with the title of 'Cases of Mortimer's Malady (lupus vulgaris multiplex nonulcerans et non-serpiginosus).' $\mathrm{He}$ begins his paper in the following way: 'I have to describe a form of skin disease which has, I believe, hitherto escaped special recognition. It may not improbably be a tuberculous affection and one of the lupus family, but if so it differs widely from all other forms of lupus both in its features and in its course.'

The clinical picture was characterized by an eruption of ' multiple, raised, dusty-red patches which have no tendency to inflame or ulcerate. They are very persistent, and extend but slowly. They occur in groups and are usually on both sides and almost symmetrical.' This publication was accompanied by beautiful colour plates of two of the patients, one of them being the Mrs. Mortimer whose name was given to the disease. 


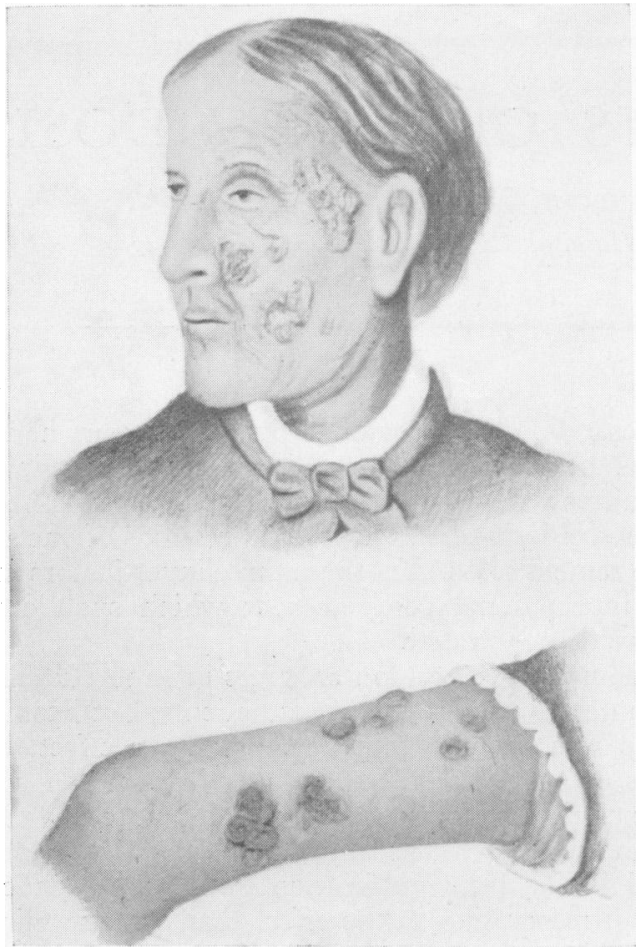

Fig. 1.-Illustration of Mrs. Mortimer in J. Hutchinson's paper 'Cases of Mortimer's Malady' in Arch. of Surgery, London, I 898.

Hutchinson was, however, careful in drawing his conclusions, and he wound up his essay on the following note: 'I have therefore thought it well at the present time to place these cases on record, hoping that the future may furnish materials for their better elucidation.'

In 1889 the Frenchman, Ernest Besnier, described a condition which he called lupus pernio, and which presented a clinical picture differing greatly from the case observed by Hutchinson. Several decades had passed before it was admitted that this clinical picture was an expression of sarcoidosis. In his first report Besnier maintained that the symptoms of the disease he described had been hitherto 'incomplétement connues et dècrites.' He mentioned the possibility that lupus pernio was related to Hutchinson's 'chilblainlupus,' i.e. lupus erythematosus, but ' non tout à fait identique.' Besnier's first case of lupus pernio also presented curious synovites of the hands.

During the following years the French literature contained several case reports (Tenneson, 1892 ; Danlos, 1901) and in 1892 Quinguaud maintained that the histological picture of the disease resembled that of lupus vulgaris, but that in cases of lupus pernio one had to deal with ' un lupus à

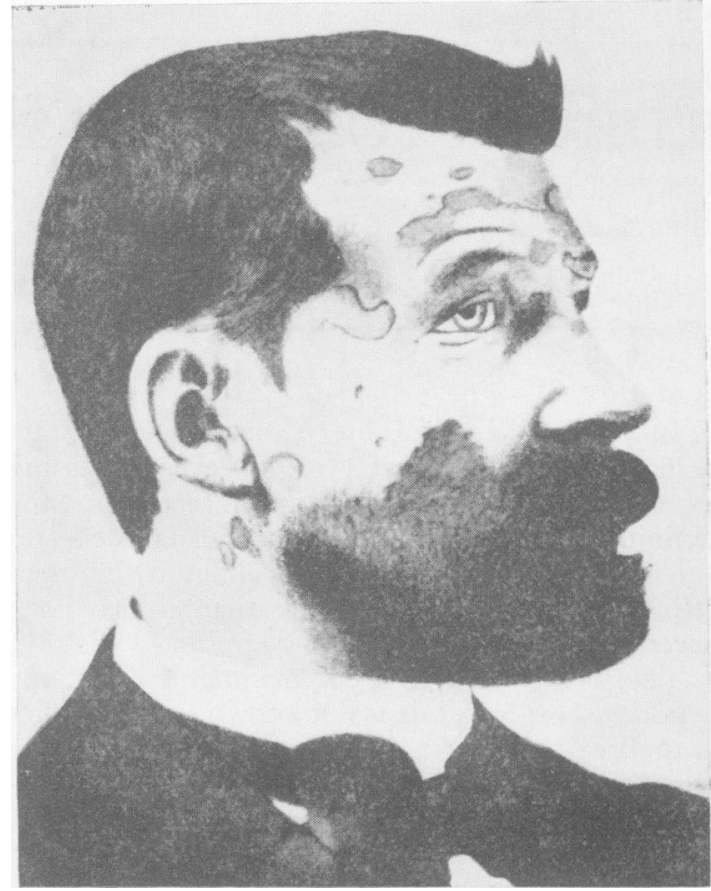

FIG. 2.- Illustration of Caesar Boeck's first patient in his paper 'Multiple Benign Sarcoid of the Skin,' f. Cutan. Dis., I 899 .

caractère histologique particulière, qu'on pourra dèfenir anatomiquement: lupus à forme myomateuse et oedèmateuse.'

It was a clinically quite different morbid picture the Norwegian Caesar Boeck demonstrated for the first time in the Medical Society of Christiania (Oslo) in 1897 and subsequently published in an American journal in 1899 . Boeck maintained that his patient represented "a form of disease which, as far as I know, has not hitherto been described, and which is most curious from both the clinical and anatomical point of view.' He called this disease 'multiple, benign, skin-sarcoid.'

Boeck made, however, as already pointed out, in his article this reservation: that his case was possibly of the same character as Hutchinson's 'Mortimer's malady.' In contrast to Hutchinson, Boeck had occasion to undertake histological investigations of the 'skin-sarcoid.' He maintained that the nodules were composed of 'compact, sharply-defined tumour foci consisting of epitheloid cells with large, pale nuclei. A few giant cells were also demonstrated.

Up to I9I6 Caesar Boeck published 23 cases of this disease, noting its localization in the skin, the superficial lymph glands, the nasal mucosa, conjunctiva and lungs. He insisted repeatedly that he was here dealing with a 'general disease.' $\mathrm{He}$ 
came gradually to believe that the disease was a ' variety of tuberculosis.' As early as I909 he had become convinced that 'lupus pernio' and ' multiple sarcoid' or 'benign miliary-lupoid,' as he called the disease later on, presented the same character in spite of the greatest differences of the clinical picture.

Among the above-mentioned three pioneers of sarcoidosis research, Caesar Boeck undoubtedly stands out as the man who carried out the most comprehensive studies of this disease. In the American literature his name is therefore often linked to the disease as 'Sarcoidosis Boeck.' This term must be considered to be better than 'Boeck's sarcoid,' hitherto the term most employed in Norway, Denmark and Germany. On the other hand, there may be good grounds for discarding personal names altogether, as other investigators have also, as already pointed out, given clinical descriptions of this disease before Boeck.

Sarcoidosis research at the beginning of this century is characterized by a series of important isolated observations which have done much to the outlining of the picture we now have of this systemic disease.

In I904 Darier and Roussy described the socalled 'subcutaneous sarcoids' presenting the histological picture of a granulation tissue whose appearance resembled that described by Boeck in his first case of ' multiple skin-sarcoid.' Darier held that this morbid picture was the expression of a tuberculide. Besnier's first case of lupus pernio also presented, as already pointed out, curious synovites of the hands.

In I9Io the German, Rieder, reported that in two of his cases of lupus pernio he had found a curious, chronic osteomyelitis of several fingers. In I919 Jüngling described similar changes with the title of ' osteitis tuberculosa multiplex cystica.'

In 1909 the Danish physician, C. F. Heerfordt, described the syndrome 'febris uveo-parotidea subchronica,' which later on, chiefly thanks to the investigations of Bruins Slot and co-workers in 1938, came to be identified as a manifestation of sarcoidosis.

Although earlier investigators had repeatedly insisted that sarcoidosis is a disease which can also involve internal organs, it remained for Kuznitzky and Bittorf to present in 1915 convincing evidence that the disease can give rise to a characteristic lung disease. Since then the localization of sarcoidosis in the lungs has been the subject of comprehensive investigations. This localization of the disease has been shown to be relatively common and it is, indeed, of so great importance that from being a ' dermatological ' disease sarcoidosis has gradually come to be regarded as of great importance to the general physician (Salvesen).
The Swede, Jörgen Schaumann (1936) is one of the investigators who has contributed greatly to sarcoidosis research in a series of studies between I9.14 and 1948, in which he throws light on the connection between the many various manifestations of this disease. In a work written in 1914, but not published till 1934, he gave an instructive account of the localization of the disease in the lungs. He has also shown that the bony changes are due to proliferation of 'sarcoid' tissue in the Haversian canals of the bones of the hands. He showed how very frequently 'sarcoid' tissue occurs in the tonsils of patients suffering from this disease and how the liver and spleen are involved. On the strength of his far-reaching studies, Schaumann proposed that the disease should be known as 'lymphogranulomatosis benigna.' This term has been employed to a certain extent in the literature, by Swedish observers in particular, but it seems now to be more and more abandoned in favour of the term 'sarcoidosis.'

With regard to the pathology of sarcoidosis, an important observation was made by the Americans, Williams and Nickerson, in 1935 and, independently of them, by the Norwegian, A. Kveim, in 194I. These investigators were able to show that an intracutaneous injection of a heat-sterilized emulsion of ' sarcoid tissue,' first and foremost from 'sarcoid ' lymphatic glands, could provoke a slowly growing nodule in the skin. The histological structure of this nodule presented the same appearance as that of spontaneous sarcoid nodules in the skin. This skin reaction has been shown to be specific to a high degree and it is of great interest, not only to the diagnosis, but also to the discussion of the pathogenesis of sarcoidosis (Danbolt, 1954).

In recent years important observations have been made, first and foremost by Swedes, with regard to the first symptoms of sarcoidosis. Löfgreen (1953), for example, has described the syndrome 'bilateral hilar lymphoma' combined with erythema nodosum. It seems that sarcoidosis in most cases begins as a lesion of the respiratory tract with subsequent extension to the lungs, glands, internal organs and skin.

In this brief survey only the most important positive findings of significance to the delineation of the disease or syndrome we now call sarcoidosis have been taken into account. Right from the time of Hutchinson, Besnier and Boeck the numerous medical discussions of the problems of sarcoidosis have been lively and to a certain extent emotional. Such discussions are bound to continue till the true cause of this disease has been found, in the near future, let us hope.

Continued on page 267. 
disease are described and illustrated by a hitherto unpublished case report of beryllium disease in a woman whose only contact with beryllium was handling 2 per cent. beryllium copper alloy sheets.

\section{BIBLIOGRAPHY}

AGATE, J. N. (I948), Lancet, ii, 530.

(:HESNER, ( $:$ (1950), Ann. intern. Med., 32, 1028.

CUR'TIS, G. H. (1951), Arch. Derm. Syph. (A.M.A. ), 64, 470.

DENARDI, J. M. VA.N, ORDS'TRAND, H. S., CURTIS, (;. H., and ZIELINSKI, J. (1953), Arch. industr. Hyg., 8, I.

(;ELMAN, I. (1936), . industr. Hyg., 18, 37 I.

GRIER, R. S., NAISH, P., and FREIMAN, D. (;. (1948), Ibid., 30, 228.

HARDY, H. L., and TABERSHAW, I. R. (1946), Ibid., 28, 197.

HARDY, H. L. (195I), Lancet, ii, 448 .

IIARDY, H. I. (1956), Amer. Rer. Tuberc., 74, 885.
JAMES, D. GERAINT (1956), personal communication.

JORDAN, W. ( I 957), personal communication.

Lancet Annotation (195I), i, I 357.

LEDERER, H., and SAVAGE, J. (1954), Brit. F. industr. Me:l. II, 45 .

LLOYD-DAVIES T. A., and HARDING, H. E. (1950), Ibid 5,671 .

MARRADI FABRONI, S. (1935), Med. d. Lavoro, 26, 297

Progress Report of the Beryllium Case Registry for 1956, Massachusetts General Hospital, Boston I4.

ROGERS, W. N. (1957), Lancet, ii, 267.

SNEDDON, I. B. ( 1955 ), Brit. med. F., i, I 448

STERNER, J. H., and EISENBUD, M. (1951), Industr. Hlth Monthly, II, 104 .

VAN ORDSTRAND, H. S., HUGHES, R., and CARMODY, M. G. (1943), Cleveland Clin. Quart., ro, ro.

VAN ORDSTRAND, H. S. (1954), Arch. industr. Hyg., 9, 232.

WEBER, H. H., and ENGLEHARDT, W. E. (I 9.33), Z. (jew H.g., IO, 4 I .

WILSON, S. A. (1948), Radiology', 50, 770 .

\section{RUTHIN CASTLE, NORTH WALES}

A Clinic for the diagnosis and treatment of Internal Diseases (except Mental or Infectious Diseases). The Clinic is provided with a staff of doctors, technicians and nurses.

The surroundings are beautiful. The climate is mild. There is central heating throughout. The annual rainfall is 30.5 inches, that is less than the average for England.

The Fees are inclusive and vary according to the room occupied.

For particulars apply to THE SECRETARY, Ruthin Castle, North Wales.

Telegrams: Castle, Ruthin

Telephone: Ruthin 66

Bibliography contimued from page 2+7-Professor Niels Danbolt, M.D. BIBLIOGRAPHY

BESNIER, E. (1898), Ann. Derm. Syph. (Paris), ro, 333.

BOECK, C. (1899), F. cutan. Dis., 17, 543.

BOECK, C. (1916), Arch. Derm. Syph. (Wien), 73, 7I.

BRUINS SLOT, W. J., GOEDBLOED, J., and GOSLINGS, J. (1938), Acta med. scand., 94, 74.

DANBOL'T, N. (1954), 'Sarcoidosis, in Mackenna: Modern 'Trends in Dermatology,' London.

DANLOS (1901), Ann. Derm. Syph. (Paris), 2, 576.

DARIER, J., and ROUSSY, G. (1904), Ibid., 5, 144.

HEERFORDT, C. F. (1909), Arch.f. Ophthalm., 70, 254.

IIUTCHINSON, J. ( 1898 ), 'Archives of Surgery,' Hutchinson, 9, 307 .

JUNGIIN(;, O. (1910), Fortschr. Rimtgenstr., 27, 375
KVEIM, A. (19+1), Nord. Med., 9, 196

KUTZNITZKY, E., and BITTORF, A. (19) 5), M. med. W'schr., 62, 1349 .

I.OFGRE.N, S. (1953), Acta med. scand., 145, 424.

RICKER, W., and CLARK, M. (r949), Amer. \%. Clin. Path., 19, 725

QUINQUAUD (1892), Ann. Derm. Syph. (Paris), 3, Iit2.

RIEDFR, H. (1910), Fortschr. Rüntgenstr., 15, 125.

SALVESEN, H. A. (1935), Acta med. siand., 86, 127

SlHaumann, J. (1936), Brit. F. Derm., 48, 399.

Tenneson, M. (1892), Ann. Derm. Syph. (Paris), 3, I I42.

WILLIAMS, R. H., and NICKERSON, D. A. (1935), Proc. Sioc. exp. Biol. (N.Y.), 33, 403 .

Bibliography comtimued from page 258-Louis E. Siltzbach, M.D.

NICKERSON, D. A. (19+1), cited by Appel, B., Arch. Derm. Syph. (Chicago), 43, 172 .

NI'TTER, L. (1953), Acta radiol. (Stockh.) (Suppl.), ro5, I-202. PEPYS, J. (1955), Amer. Rev. 'Tuberc., 71, 49.

PUTKONEN, T. (1943), Acta derm.-7enereol. (Stockh.) (Suppl.), 23, $1-194$.

QUINN, E. L., BUNCH, D. C., and YA(iEL, E. M. (1955), F. invest. Derm., 24, 595 .

REFVEM, O. (1954), Acta med. scand. (Suppl.), 294, I-1 46.

REID, J. D. (1956), N.Z. med. F., 55, 275.

ROGERS, F. J., and HASERICK, J. R. (1954), F. invest. Derm., 23, 389 .

ROSTENBERG, A., SZYMANSKI, F. J., BREBIS, G. J., HAEBERLIN, J. B., and SENEAR, F. E., (1953), Arch. Derm. Syph. (Berl.), 67, 306.
SANDS, J. H., PAL.MER, P. P., MAYOCK, R. I., and ('REGER, W. P. (1955), Amer. Ұ. Med., 19, 401 SCADDING, J. (j. (1956), Tubercle, 37, 371 .

SCHIER, W. W., ROTH, A., OSTROFF, G., and SCHRIFT, M. H. (1956), Amer. F. Med., 20, 94.

SEEBERG, G. (1951), Acta derm.-venereol. (Stockh.), 3 I, 426. SILTZBACH, L. E., and EHRLICH, J. C. (1954), Amer. F. Med.
16, 790 .

SILTZBACH, I. E. (1957), Ibid., 22, 84I.

SONES, M., and ISRAEL, H. L. (1954), Ann. intern. Med., 40, 260 SONES, M., ISRAEI, H. I., KRAIN, R., and BEERMAN, H. (1955), $\mathcal{F}$. invest. Derm., 24, 353.

TEILUM, G. (1948), Amer. F. Path., 24, 389.

ZETTERGREN, L. (1954), Acta Śoc. Med. upsalien. (Suppl.), 